\title{
Z8-200 em decurso: caminhos e impasses da preservação cultural por zoneamento em São Paulo nos anos 1980'
}

Z8-200 in progress: paths and impasses in the cultural preservation through zoning in São Paulo (São Paulo, Brazil) during the 1980s

https://doi.org/10.1590/1982-02672020v28d2e56

\section{MARIANA CAVALCANTI PESSOA TONASSO²}

https: //orcid.org/0000-0002-2445-8599

Universidade de São Paulo / São Paulo, SP, Brasil

RESUMO: Em 1975, foi instituído na cidade de São Paulo o primeiro instrumento municipal de preservação do patrimônio cultural: a Zona Especial Z8-200. Seu estabelecimento significou o início de uma experiência inovadora em São Paulo, coerente com outras iniciativas urbanísticas de preservação da época, a exemplo do Corredor Cultural do Rio de Janeiro (de 1979). Como parte da lei geral de zoneamento, a Z8-200 representou uma alternativa ao tradicional tombamento, uma vez que este ainda não havia se estabelecido em nível municipal. Sua estruturação era bem fundamentada e permeada de diretrizes urbanísticas, porém sua aplicação prática apresentou algumas limitações importantes. Após uma breve caracterização do instrumento e de seus antecedentes, este artigo se propõe a discutir principalmente os desdobramentos e contradições relacionados à implementação da Z8-200 no decorrer dos anos 1980. O período é marcado, por um lado, pela regulamentação do instrumento, buscando normatizar e incentivar a preservação por zoneamento, em reação à perda de bens culturais significativos na cidade. Por outro lado, a mesma década presenciou um esvaziamento do instrumento, suscetível às circunstâncias políticas, abrindo caminho para o estabelecimento do Conselho Municipal de Preservação do Patrimônio Histórico, Cultural e Ambiental da Cidade de São Paulo (Conpresp), que assumiria a prerrogativa de zelar pelos bens culturais da cidade.

\begin{abstract}
1. Este trabalho é parte de uma pesquisa de mestrado que abrange o percurso histórico, conceitual e metodológico de criação das Zonas Especiais de Preservação Cultural (Zepecs) na cidade de São Paulo - desde a Z8200, criada em 1975 para integrar a Lei Geral de Zoneamento de 1972, à atual Zepec, criada no Plano Diretor Estratégico (PDE) em 2002 e detalhada na lei que unifica o Zoneamento e Planos Regionais das Subprefeituras de 2004. Neste caminho, foram problematizas as relações entre o planejamento urbano e a preservação do patrimônio cultural na cidade, na figura de seus principais instrumentos: 0 zoneamento e o tombamento, respectivamente.
\end{abstract}

2. Arquiteta e urbanista graduada pela Faculdade de Arquitetura e Urbanismo da Universidade de São Paulo (FAUUSP), mestre em Arquitetura e Urbanismo na área de História e Fundamentos da Arquitetura e do Urbanismo pela mesma instituição e docente no curso de Arquitetura e Urbanismo. Participa 
do Grupo de Pesquisa "Patrimônio Cultural: História e Crítica" (2016). E-mail: <marianacpessoa@gmail.com>.
PALAVRAS-CHAVE: Patrimônio cultural. Políticas de preservação. Zoneamento urbano.

ABSTRACT: In 1975, the first instrument for cultural heritage preservation was established in São Paulo, São Paulo, Brazil: the Z8-200 Special Zone. Its constitution meant the beginning of an innovative experience in the city, consistent with other urban preservation initiatives of that period, such as the 1979 Corredor Cultural in Rio de Janeiro. As part of the general zoning law, the Z8-200 represented an alternative to the traditional Heritage List, as it had not been established at the municipal level at that point. Its structure was well-founded and permeated with urban guidelines, although it presented some important limitations in practice. After a brief characterization of the instrument and its background, this article discusses the development and contradictions related to its implementation during the 1980s. This period is marked, on the one hand, by the regulation of the instrument, seeking to strengthen and encourage preservation through zoning, in reaction to the loss of significant cultural buildings in the city. On the other hand, the same decade witnessed the instrument's emptying, susceptible to political circumstances, paving the way for the establishment of the Municipal Council for Preservation (Conpresp), which would assume the prerogative to defend the city's cultural heritage.

KEYWORDS: Cultural heritage. Preservation policy. Zoning law. 


\section{INTRODUÇÃO}

A trajetória institucional de preservação do patrimônio cultural na cidade de São Paulo possui uma histórica ligação com o setor de planejamento urbano devido a um instrumento criado nos anos 1970: a Zona Especial Z8-200. Esta foi integrada em 1975 à antiga Lei Geral de Zoneamento, ${ }^{3}$ que regulava o parcelamento, o uso e a ocupação do solo no território municipal a partir de sua classificação em oito zonas de uso, posteriormente ampliadas. A última delas (Z8) era reservada aos usos especiais e contemplava, entre outros, espaços sujeitos a preservação ou controle específico, tais como os "monumentos históricos". 4 Essa zona de preservação foi concebida, portanto, para se ocupar da "preservação dos imóveis de caráter histórico ou de excepcional valor artístico, cultural ou paisagístico" 5 no município de São Paulo e foi a primeira política de salvaguarda do patrimônio a se consolidar na cidade.

A Z8-200 representou uma experiência inovadora em São Paulo e uma alternativa ao tradicional tombamento, uma vez que este ainda não havia sido instituído em nível municipal. Na ocasião, foi possível realizar um programa de preservação permeado de diretrizes urbanísticas e bem estruturado do ponto de vista teórico e metodológico. Também existiram, contudo, algumas limitações conceituais e práticas importantes, como critérios de seleção comprometidos com questões sobretudo formais, certo apego aos valores estético-estilísticos, em detrimento da apropriação social, e vulnerabilidade às vicissitudes políticas. ${ }^{6}$ Quando da criação dessa zona, a cidade de São Paulo passava por significativas transformações espaciais e urbanísticas, dentre elas o acelerado processo de verticalização, a expansão para além das áreas centrais e as obras para a implantação do metrô entre 1968 e 1974, que provocaram expressivo arrasamento do tecido urbano.7 As demolições "necessárias" para a implantação desses grandes empreendimentos, como as do Palacete Santa Helena (1972) e do Edifício Mendes Caldeira (1975), ou a ameaça de demolição da antiga Escola Normal Caetano de Campos (1975), teriam ocasionado o surgimento de uma nova sensibilidade em relação ao patrimônio municipal. ${ }^{8}$ Lembrando que tudo isso transcorria no período mais fechado do regime civil-militar, não havendo espaço para debates ou questionamentos. ${ }^{9}$ Nesse contexto, o setor de planejamento buscou mapear as edificações "dignas" 10 de serem preservadas na área central da cidade de São Paulo, antes que estas fossem perdidas no processo.

A primeira listagem de bens arquitetônicos pertencentes à Z8-200, em 1975, tinha um caráter mais indicativo e era composta de 93 itens. Entre estes, encontravam-se alguns imóveis isolados e sobretudo "manchas" urbanas,
3. São Paulo (1972).

4. Id. (1971b).

5. Id. (1975b).

6. Tonasso (2019, p. 21).

7. Rodrigues (2016, p. 38).

8. Andrade (2012, p. 5); Zanetti (2005, p. 260).

9. Zanetti, op. cit., loc. cit.

10. Cf. Somekh (2015). 
11. Lemos (1976, p. 33).

12. Andrade, op. cit.

13. São Paulo (1975b).

14. São Paulo (1977).

15. Andrade, op. cit., p. 88. abrangendo conjuntos de edificações consideradas significativas de alguns dos ciclos econômicos da cidade de São Paulo. A seleção dos bens dessa lista foi conduzida pelos arquitetos Benedito Lima de Toledo e Carlos Lemos, a convite da direção da antiga Coordenadoria Geral de Planejamento (Cogep). Segundo o arquiteto, toda a região central de São Paulo foi percorrida nessa ocasião, juntamente com uma equipe de estudantes de arquitetura, para identificar bens de interesse para a preservação. A princípio, eles teriam realizado um "levantamento sumário" das construções urbanas que "merecessem atenção por suas qualidades arquitetônicas ou históricas"1l - levantamento este que seria posteriormente revisitado e aprofundado. A pesquisa de Andrade ${ }^{12}$ documenta os trabalhos de inventário em São Paulo da década de 1970, incluindo o da Z8-200, e traz entrevistas com seus autores, analisando parte desse processo e suas motivações.

A Z8-200 foi instituída através da Lei Municipal n 8.328/1975, juntamente com outras zonas de uso que passaram a integrar o zoneamento municipal. Nessa lei, as determinações destinadas aos bens enquadrados nos limites da zona de preservação eram ainda bastante sucintas e genéricas. $O$ regulamento estabelecia apenas que os usos ali permitidos eram os mesmos da zona circundante e advertia que as intervenções naquelas áreas ficariam sujeitas à prévia autorização da Cogep, que ouviria, se necessário, o Conselho de Defesa do Patrimônio Histórico, Arqueológico, Artístico e Turístico do Estado de São Paulo (Condephaat). ${ }^{13}$ Além disso, foi determinado que as normas para apreciação dos casos de intervenção, tais como remembramento ou desdobro de lotes, demolições, reformas, ampliações, reconstruções ou novas edificações, seriam baixadas por atos do Executivo. Ou seja, até então, a lei trazia apenas uma breve descrição dos itens selecionados e os colocava sob controle do órgão de planejamento, sem deixar claros os contornos e as motivações para a preservação.

Poucos anos depois da entrega desse levantamento e da criação da Z8200, Toledo e Lemos foram novamente convidados a dar continuidade ao processo e a elaborar o devido inventário dos bens. $\bigcirc$ trabalho, denominado Programa Toledo/Lemos para a preservação de bens culturais arquitetônicos da área central de São Paulo, ${ }^{14}$ foi entregue em 1977, mesmo ano em que se constituiria o quadro técnico da Divisão de Preservação do Departamento do Patrimônio Histórico (DPH), pertencente à Secretaria de Cultura. Essa divisão seria responsável por realizar as pesquisas relacionadas ao patrimônio preservado na cidade, vindo depois a contribuir com estudos de novas propostas para a Z8-200. O Programa Toledo/ Lemos revisou e aprofundou os trabalhos realizados para a elaboração da primeira lista, com pesquisas sobre os imóveis, propostas de graus de preservação e modelos legislativos. ${ }^{15}$ Nessa etapa, os edifícios teriam sido abordados "a nível 
de lote, com pesquisa e análise de todos os interiores", demandando "exaustivos trabalhos de reconhecimento e documentação". ${ }^{16}$ A normatização da Z8-200 prevista desde sua criação seria baseada nesses estudos, mas conseguiu ser regulamentada apenas na década seguinte.

Através da análise de fontes primárias, como leis e documentos armazenados nos arquivos da Secretaria Municipal de Desenvolvimento Urbano (SMDU), dialogando também com agentes envolvidos no processo e pesquisas correlatas, este artigo pretende discutir principalmente os desdobramentos relacionados à aplicação e busca pela consolidação da Z8-200 por volta dos anos 1980. Isto porque a partir desse período se estabeleceriam importantes marcos legais para assegurar e incentivar a preservação do patrimônio cultural pelo zoneamento. Essa legislação, no entanto, seria proposta em reação a novas perdas de bens culturais significativos na cidade de São Paulo, a despeito da existência da Z8-200 desde 1975.

Também nessa década seria lançada uma publicação bastante expressiva a respeito do patrimônio paulistano, intitulada Bens culturais arquitetônicos no município e na Região Metropolitana de São Paulo, estruturada a partir do levantamento dos bens protegidos na cidade até 1984. Conhecida como "tijolinho", a publicação tinha o objetivo de organizar e divulgar os bens culturais de reconhecido valor para a formação histórico-cultural da Região Metropolitana de São Paulo, de modo a "sensibilizar o conjunto de pessoas afetas à questão... ou seja, todos aqueles que direta ou indiretamente decidem e intervêm no espaço representativo da cultura". ${ }^{17}$

A década de 1980 também é marcada, por outro lado, pelo estabelecimento do órgão municipal de preservação do patrimônio cultural, que assumiria essa competência em lugar do setor de planejamento urbano. Muitos dos bens inventariados para a Z8-200, inclusive, só encontrariam possibilidade de proteção legal com o início dos tombamentos pelo Conselho Municipal de Preservação do Patrimônio Histórico, Cultural e Ambiental da Cidade de São Paulo (Conpresp), criado em 1985 e que passaria a atuar ao final de 1988. Portanto, ao passo que a preservação através do zoneamento buscava se consolidar, ocorria uma transição na gestão do patrimônio municipal, passando do Planejamento à Cultura.

A decisão de iniciar a trajetória de preservação paulistana com o zoneamento é lastreada por uma série de fatores que se relacionam com o contexto de discussões e experiências preservacionistas do período, as circunstâncias políticas e a posição de destaque que esse dispositivo vinha conquistando como principal instrumento de planejamento. ${ }^{18}$ As iniciativas envolvendo a preservação e o planejamento urbano vinham acontecendo desde os anos 1960 em várias partes do mundo, a exemplo das "áreas de conservação" implementadas em países
16. São Paulo (1977).

17. Secretaria de Estado dos Negócios Metropolitanos; Empresa Metropolitana de Planejamento da Grande São Paulo; Secretaria Municipal do Planejamento (1984, p. 7).

18. Feldman (2005, p. 27). 
19. Castriota (2010, p. 62).

20. Nascimento (2018).

21. Cf. Instalação... (2008).

22. São Paulo (1971a, p. 2).

23. Ibid.

24. A composição previa a representação dos seguintes órgãos e instituições: (1) Secretaria Municipal de Educação e Cultura; (2) Departamento de História da Faculdade de Filosofia, Ciências e Letras da Universidade de São Paulo; (3) Diretoria do Patrimônio Histórico e Artístico Nacional; (4) Instituto Histórico e Geográfico de São Paulo; (5) Serviço de Museus Históricos do Estado de São Paulo; (6) Instituto dos Arquitetos do Brasil, seção de São Paulo; (7) Órgão do Planejamento Urbano Integrado do Município; (8) Cúria Metropolitana de São Paulo; (9) Instituto de Engenharia de São Paulo; e (10) Instituto Genealógico Brasileiro (ibid.).

25. São Paulo (1968, 1971a).

26 Instalação..., op. cit. como Holanda, França, Inglaterra e Estados Unidos, ${ }^{19}$ e também passaram a ser empreendidas no Brasil a partir dos anos 1970, como na reconhecida experiência do Corredor Cultural no Rio de Janeiro. ${ }^{20}$ Em São Paulo, contudo, esse caminho não foi isento de discordâncias ou tentativas divergentes. Antes de tratar do desenvolvimento da Z8-200, é relevante destacar outra iniciativa, pouco conhecida e pesquisada, de criar um conselho municipal de preservação inspirado no órgão estadual Condephaat: o Condepam, de 1971.

\section{ANTECEDENTES: A BREVE EXISTÊNCIA DO CONDEPAM}

No ano de 1971, ao final da primeira gestão do prefeito Paulo Salim Maluf, foi criado na cidade de São Paulo o Conselho de Defesa do Patrimônio Histórico e Cultural do Município (Condepam). ${ }^{21}$ Segundo o decreto que o instituiu, competia a esse órgão a adoção das medidas necessárias à defesa dos bens e locais de valor histórico, artístico, turístico e arqueológico do município. Para justificar sua criação, argumentou-se que essa atribuição específica, por sua natureza "peculiar", requeria um cuidado especial, que só seria possível encontrar em "órgãos coletivos integrados por elementos de notória dedicação a tais assuntos". ${ }^{22} \bigcirc$ argumento, portanto, era que apenas uma instituição formada por pessoas reconhecidamente dedicadas ao tema do patrimônio poderia zelar por esses bens na cidade.

Diante dessa percepção, era prevista por decreto a reunião de oito membros "de comprovada idoneidade e com notórios conhecimentos relativos às finalidades do órgão", ${ }^{23}$ designados pelo prefeito, para compor o Conselho. Entre eles, seriam nomeados representantes da administração pública municipal e da sociedade civil, como membros do Executivo, de instituições públicas, das universidades e de entidades profissionais. ${ }^{24}$ As funções de membro do conselho seriam exercidas pro honore, ou seja, sem direito a remuneração. Já os recursos humanos para compor o quadro técnico e administrativo do órgão seriam disponibilizados pela então Secretaria Municipal de Educação e Cultura.

É possível perceber, inclusive pela escolha dos termos utilizados para definir suas atribuições e competências, que ○ Condepam foi inspirado no Condephaat, criado contemporaneamente (em 1968). Um indício é o fato de o art. $2^{\circ}$ da lei que instituiv o órgão estadual ter sido replicado ipsis litteris na legislação do Condepam. ${ }^{25}$ Além disso, a composição proposta para o Conselho do Município era bastante plural e similar àquela instituída para o órgão estadual. Por fim, a própria prefeitura de São Paulo reconhece que ele foi criado "nos moldes do Condephaat". 26 
Entre as medidas para a defesa dos bens culturais previstas na lei, figura a adoção de instrumentos como o tombamento e a desapropriação. Mayumi considera, no entanto, que o órgão funcionou apenas de modo "consultivo e opinativo", tendo como atribuições "propor o tombamento às autoridades competentes e promover estudos [...] sobre as providências destinadas à colaboração" do município com os serviços federal e estadual do patrimônio cultural. ${ }^{27}$ Um exemplo de sua atuação pode ser observado em processo referente à Casa do Tatuapé, residência bandeirista tombada pelo Instituto do Patrimônio Histórico e Artístico Nacional (Iphan) em 1951. Na ocasião, o então presidente do Condepam e chefe do Arquivo Histórico, José Eduardo do Nascimento, informou ao secretário de Cultura a decisão do Conselho de recomendar à administração "providências para a defesa e a restauração do imóvel", também sugerindo solucionar "a irregularidade da construção de moradias, não autorizada pelo Iphan, que rouba a visibilidade do monumento". ${ }^{28}$

As informações sobre a atuação e o desfecho do Condepam são escassas; contudo, consta em um registro da prefeitura que o órgão municipal não conseguiu se consolidar ou levar adiante suas propostas, tendo uma vida bastante curta. ${ }^{29} \mathrm{Em}$ 1972, ano subsequente à sua criação, o arquiteto Luís Saia já demonstrava descrença no êxito do órgão em artigo publicado na revista A construção em São Paulo. Nele, o arquiteto reconhecia a importância de tombar exemplares da arquitetura paulistana que possuíssem "especial significado na marcação de seu desenvolvimento", porém compreendia que o Conselho, da maneira como estava organizado, parecia "não desfrutar das condições mínimas de funcionamento". ${ }^{30}$

Já em 1973, poucos dias antes de terminar a gestão do então prefeito Figueiredo Ferraz, o Condepam foi reestruturado através de um decreto municipal que determinava seu funcionamento como órgão de consulta e assessoria do prefeito. ${ }^{31}$ Sua composição também foi alterada, passando a dispor de sete conselheiros e três suplentes, nomeados pelo prefeito, além de um arquiteto para atuar como consultor técnico. Desta vez, no entanto, não foram discriminados os órgãos ou entidades a serem representados, obscurecendo sua organização. Pouco depois, Miguel Colasuonno assumiu a prefeitura da cidade e, durante sua administração, a preservação cultural seria acolhida pelo setor de planejamento urbano municipal.

Ao buscar sintetizar a trajetória desse Conselho Municipal, a prefeitura relata que o órgão de "vida efêmera e com percalços administrativos [...] nasceu e morreu lutando para sobreviver". Entre os motivos que ocasionaram esse esmorecimento, são citadas questões políticas como "falta de autonomia para deliberação" e "crises de autoridade", o que teria tornado "impossível a participação de pessoas interessadas em promover a preservação da memória paulistana", que era a principal justificativa para a sua existência. Apesar de não conseguir concretizar suas propostas, segundo
29. Cf. Instalação..., op. cit. 30. Saia (1972) apud Fenerich $(2000$, p. 51$)$.

31. São Paulo (1973). 
32. Instalação..., op. cit.

33. Andrade, op. cit., p. 73.

34. Fré (2018).

35. Baffi (2006, p. 173). a prefeitura, o órgão teria realizado um "intenso trabalho", conforme demonstram os processos armazenados em seu Arquivo Geral. ${ }^{32}$

É importante destacar a existência dessa primeira tentativa de organizar uma política de preservação na cidade de São Paulo, com a estruturação de uma instituição, de agentes atuantes e de instrumentos, para demonstrar que havia uma discussão no período a respeito da preservação por tombamento e que existiram outros movimentos para além daquele caminho que se institucionalizou como o embrião da preservação no município. As questões patrimoniais seriam inseridas de maneira mais sólida na legislação urbanística da cidade em 1975, por intermédio da Z8-200, em caminho que divergia da percepção de que apenas um órgão específico de patrimônio poderia zelar pelos bens culturais da cidade. Na década de 1980, no entanto, essa questão voltaria a ser discutida, e um novo órgão municipal de preservação seria criado.

\section{CAMINHOS E IMPASSES NA APLICAÇÃO DA Z8-200 NOS ANOS 1980}

Oniverso das primeiras edificações e conjuntos urbanos enquadrados na Z8-200, como mencionado, foi a área central da cidade de São Paulo. Porém, com o decorrer dos anos, a metodologia desenvolvida no Programa Toledo/Lemos para a Cogep foi aplicada em novos estudos..$^{33}$ Segundo Sylvia Fré, arquiteta que trabalhava com o tema da preservação no setor de planejamento da prefeitura, a lógica utilizada na escolha dos bens estudados a partir de então era predominantemente espacial. ${ }^{34}$ Ou seja, quando o setor de planejamento estava tratando de determinada área da cidade onde seria gerado impacto, aproveitava para proteger certos imóveis que poderiam sofrer descaracterizações ou demolições. Esse foi o caso, por exemplo, do inventário da Zona Metrô Leste (ZML), realizado em 1978 em parceria com o DPH. De acordo com Baffi, na época foi submetido um projeto à Câmara Municipal propondo a inclusão dos imóveis desse inventário na Z8-200, mas ele teria sido recusado em virtude das pressões exercidas por proprietários de imóveis industriais pertencentes à listagem. ${ }^{35}$

Mesmo com a ampliação dos inventários e com novos enquadramentos na Z8-200 até meados dos anos 1980, os bens preservados se mantiveram ainda bastante limitados a uma pequena parcela do território municipal. $\bigcirc$ levantamento realizado por Toledo e Lemos começou na região central da cidade, mas a proposta era que se expandisse. Prova disso é que o "tijolinho" contemplava também a Região Metropolitana de São Paulo. Ao se analisar a distribuição geográfica desses bens, no entanto, é possível perceber que a grande concentração de conjuntos e edificações 
protegidos permaneceu ainda no centro da cidade. Na "Nota explicativa", os responsáveis admitem essa confluência, atribuindo-a ao estágio inicial dos trabalhos e à tentativa de controle da dinâmica imobiliária, além de reconhecerem que os bens de interesse para a preservação estariam, na realidade, disseminados por todo o território:

Constata-se que as manchas e os bens culturais isolados [...] se localizam, em sua grande maioria, na Área Central, uma das que mais sofrem com a pressão da renovação imobiliária. Contudo, deve-se ter em mente que os exemplares dignos de conservação se encontram disseminados por toda a cidade, e que o trabalho de identificação e proteção desses bens só pode ser conduzido de modo sistemático e incessante. Mesmo na Área Central, uma região exaustivamente pesquisada, ao observador atento não passarão despercebidas omissões provocadas por motivos diversos. Elas deverão ser reparadas em momento oportuno. ${ }^{36}$

Os mapas presentes na publicação, por serem fragmentados, não ajudam muito na percepção do cenário total. Assim, esta pesquisa buscou conciliar o mapeamento de todos os bens da Z8-200 a partir do banco de dados da Secretaria Municipal de Desenvolvimento Urbano (SMDU), constatando que a proporção desses itens, em confronto com a área total da cidade, é muito reduzida e circunscrita. Quase todos eles permaneceram concentrados na coroa central, e a extensão das manchas, ao se ampliar a visão da cidade, faz com que os pouquíssimos bens arrolados nas franjas desapareçam do campo de visão (Figura 1). É importante notar a existência de uma região privilegiada (Figura 2), denotando que a área alcançada por esse instrumento é ainda bastante limitada.

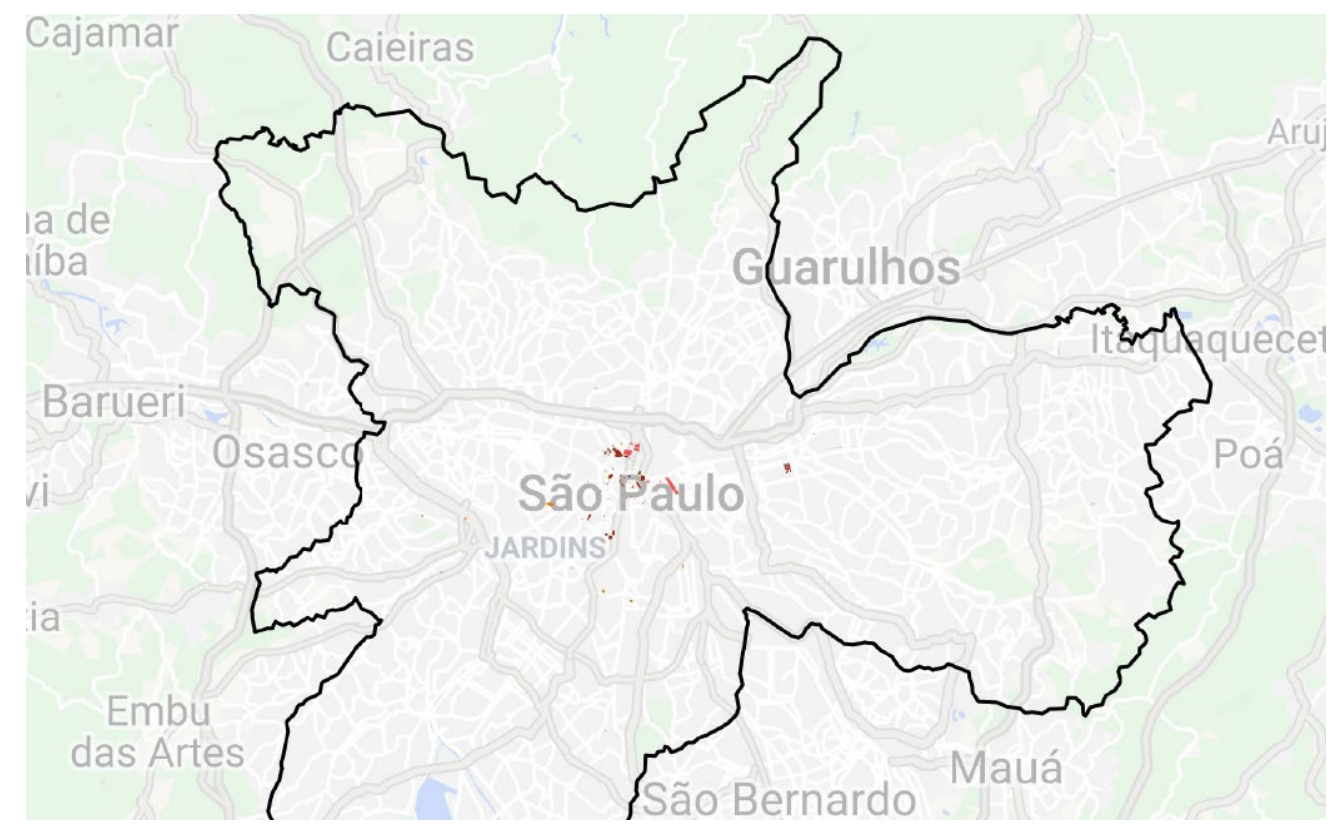

36. Secretaria de Estado dos Negócios Metropolitanos; Empresa Metropolitana de Planejamento da Grande São Paulo; Secretaria Municipal do Planejamento, op. cit., p. 95.

Figura 1 - Mapa da Z8-200, São Paulo, 2017. Na vista expandida do mapa percebe-se o quão restrita é a área que concentra os bens preservados. Fonte: Google Maps, retrabalhado pela autora com dados fornecidos pela SMDU e GeoSampa. 
37. Mapeamento realizado em 2017 e atualizado em 2019.

38. Fré, op. cit.

39. Entre estes, localizamos propostas sobre: um imóvel na Vila Jaraguá (PL $\mathrm{n}^{\circ}$ 592/1989); a Chácara das Flores, no Itaim Paulista (PL $\mathrm{n}^{\circ}$ 43/1990); um conjunto de imóveis no bairro de Santa Cecília (PL $\mathrm{n}^{\circ}$ 236/1990); o Parque do Povo (PL n $\left.{ }^{\circ} 355 / 1990\right)$; a área do Outeiro da Freguesia do Ó (PL n $\left.{ }^{\circ} 141 / 1991\right)$; o Cemitério da Vila Alpina (PL $n^{\circ}$ 485/1993); um imóvel na área de entorno do Parque da Independência (PL $\mathrm{n}^{\circ}$ 758/1995); e o Complexo Penitenciário do Carandiru (PL n ${ }^{\circ}$ 763/1996).

40. Informação verbal. Entrevista concedida à autora em 5 de setembro de 2018 .

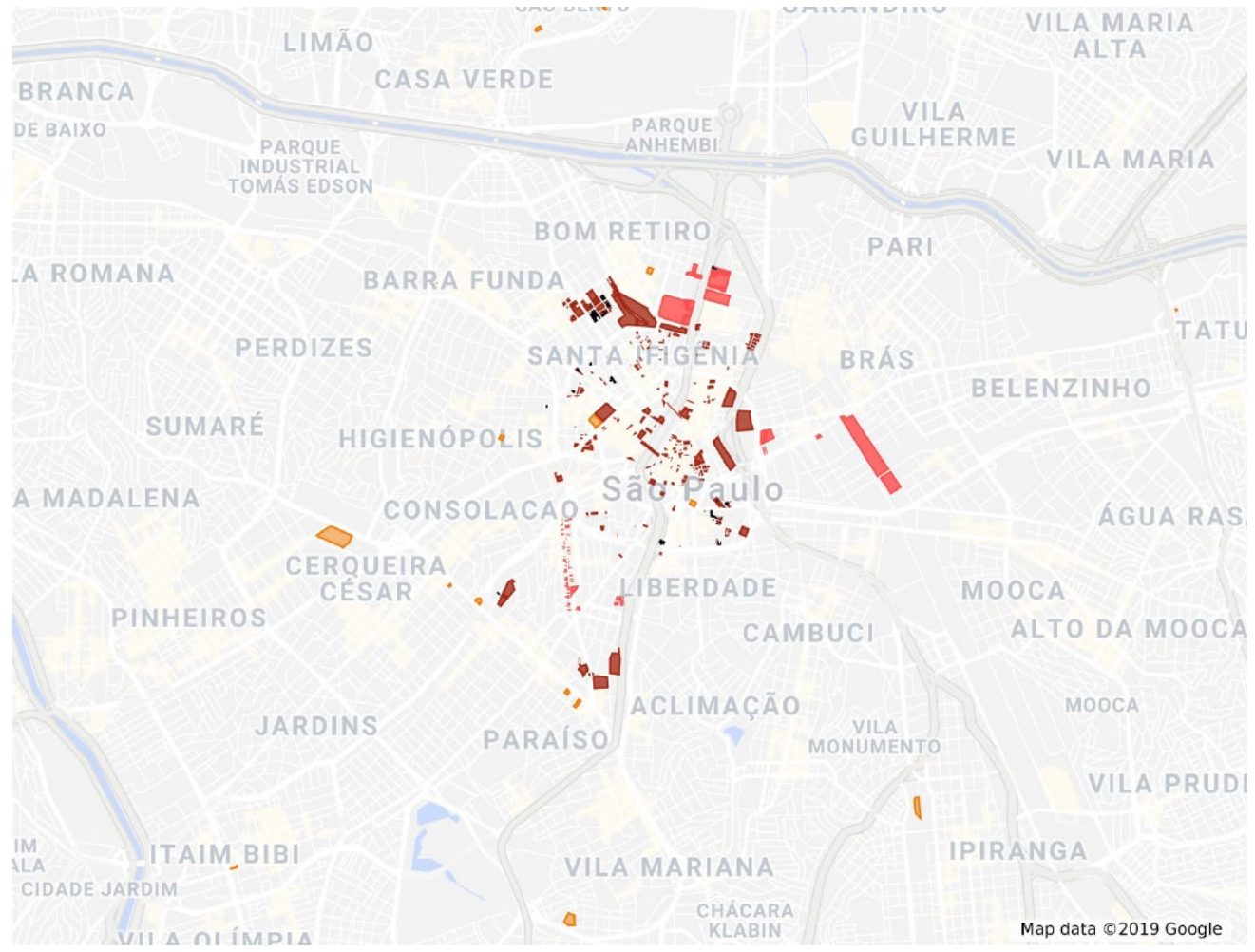

Figura 2 - Ampliação da principal área de concentração de bens da Z8-200, São Paulo, 2019. As cores se referem ao ano de enquadramento desses bens. ${ }^{37}$ Fonte: Google Maps, retrabalhado pela autora com dados fornecidos pela SMDU e GeoSampa.

Os estudos e novos enquadramentos na Z8-200 funcionaram melhor até 1984, segundo Fré, porque com os governos pós-abertura democrática não teria havido muito interesse em apresentar novas propostas, uma vez que estas implicavam proibir a demolição ou restringir a reforma de propriedades majoritariamente privadas. Ainda de acordo com a arquiteta, os estudos de proteção teriam continuado, mas as propostas eram constantemente engavetadas. ${ }^{38}$ As Atas das Sessões Plenárias da Câmara Municipal do período de fato registram alguns Projetos de Lei (PL) com propostas de novas áreas para enquadramento na Z8-200, mas os debates eram frequentemente adiados sob o pretexto de que existiam discussões maiores em andamento sobre o planejamento da cidade. ${ }^{39}$

Walter Pires, técnico que atuou no Condephaat de 1982 até 1991 lquando se vinculou ao DPH), acredita que o fato de a Z8-200 depender de viabilização através da Câmara Municipal teria limitado em princípio sua ampliação, por conta de vicissitudes, interesses e pressões..$^{40}$ Neste sentido, apenas quando existia uma situação política favorável era possível encaminhar as propostas oriundas do trabalho 
da equipe envolvida e consequentemente aprovar o enquadramento de novas áreas, o que teria sido difícil manter com o passar dos anos e as mudanças de governo.

Também em 1984 seriam aprovadas leis que buscavam fortalecer a defesa do patrimônio através do zoneamento. Apesar de terem se revelado insuficientes para garantir a proteção dos bens culturais na cidade, tais leis visavam incentivar a preservação, compensando os proprietários de imóveis protegidos, além de estabelecer limites e critérios para a aprovação de intervenções nessas áreas, justificando, respaldando e evitando subjetividade nas decisões.

\section{A TRANSFERÊNCIA DO POTENCIAL CONSTRUTIVO}

No início do mês de julho de 1984, foi aprovada uma lei que dispunha sobre a transferência do potencial construtivo para o município de São Paulo, estabelecendo incentivos, obrigações e sanções relativas à preservação de imóveis enquadrados na Z8-200. ${ }^{41}$ A criação dessa lei, segundo Somekh, estaria relacionada ao "trauma" gerado pela extinção de edifícios marcantes na cidade. ${ }^{42} \mathrm{O}$ episódio mais conhecido ocorrev em 1982, quando foram demolidos repentinamente três dos últimos casarões da Avenida Paulista após uma declaração precipitada do então presidente do Condephaat, Ruy Ohtake, de que eles deveriam ser tombados. Essas demolições provocaram fortes reações da imprensa e da população à época. Nascimento compreende que "o choque [...] não poderia ser pela novidade da experiência [que também havia motivado a listagem de bens para a Z8-200], e sim pelo sentimento já conhecido pela população de perda de seus espaços de memória". ${ }^{43}$

A resistência contra essas perdas culminou numa proposta de lei da Secretaria do Estado à Câmara Municipal, ainda em 1982, que, contudo, foi arquivada na sequência. $\bigcirc$ assunto retornou em 1984, quando o prefeito Mário Covas e seu secretário Jorge Wilheim encaminharam à Câmara Municipal um PL baseado no anterior, proposto por Modesto Carvalhosa e Benedito Lima de Toledo. ${ }^{44} \mathrm{O}$ mecanismo desse instrumento, segundo Rabello, "reconhece, de certa forma, que o proprietário, antes mesmo de construir em seu imóvel, o que a legislação urbanística the faculta, este poderia alienar o que sempre foi considerado, pela jurisprudência pátria, uma expectativa de direito". ${ }^{45}$ Ou seja, além do direito de propriedade, está implícita a existência de um direito de construir naquela propriedade, embora este esteja subordinado aos índices construtivos previstos pela administração municipal através da lei de uso e ocupação do solo.
41. São Paulo (1984a).

42. Somekh, op. cit.

43. Nascimento (2016, p 106).

44. Cf. Somekh, op. cit. 45. Rabello (2010, p. 47), grifo meu. 
47. Ibid., art. $5^{\circ}$.

48. Ibid., arts. $7^{\circ}$ e $8^{\circ}$.

49. Ibid., art. 13 .
Um dos índices estabelecidos nas leis urbanísticas para regular o direito de construir é o coeficiente de aproveitamento do solo, um valor que, multiplicado pela área do lote, indica a quantidade máxima de metros quadrados que podem ser construídos em um terreno, somando-se as áreas de todos os pavimentos. A legislação considerava "potencial construtivo" o produto da área do lote pelo coeficiente de aproveitamento de sua zona de uso. ${ }^{46} \mathrm{Ou}$ seja, cada lote possui um potencial construtivo que, no caso dos bens culturais protegidos, frequentemente não é atingido em seu limite, nem há possibilidade de aproveitáto por completo. Assim, o instrumento permitia que o potencial não utilizado fosse transferido para outro lote daquele proprietário ou alienado, de modo que o comprador pudesse aplicá-lo em suas terras.

A aplicação desse mecanismo nos anos 1980, no entanto, era ainda restrita. Era autorizada a transferência de até $60 \%$ do potencial construtivo do imóvel preservado, exceto quando este fosse destinado à instalação de atividades que possibilitassem a fruição pública. ${ }^{47}$ Além disto, o potencial construtivo transferido só poderia ser exercido em imóveis situados no perímetro de entorno do imóvel preservado e apenas em zonas de uso específicas. No caso de uma zona predominantemente residencial, por exemplo, o imóvel precisaria estar contido num raio de mil metros de um bem enquadrado na Z8-200.48 Ou seja, além do proprietário não conseguir transferir todo o potencial, o interessado em adquiri-lo enfrentava diversas restrições no aproveitamento.

Para a solicitação da transferência, a lei descrevia alguns requisitos, mas nenhum deles atrelava a concessão à comprovação de bom estado de conservação do edifício ou ao compromisso de utilizar o recurso para esse fim. A norma apenas ratificava que a conservação e os reparos nesses imóveis eram uma obrigação do proprietário, o que significa que o recurso não precisava necessariamente ser empregado na preservação desse bem. No entanto, caso o bem não fosse preservado ou fossem feitas intervenções sem autorização da Sempla, o proprietário deveria pagar uma multa e restituir o imóvel às condições anteriores. Já a destruição ou a demolição teriam consequências mais rigorosas, como a perda de benefícios e restrições no aproveitamento do terreno remanescente, que só poderia ser utilizado para construir uma residência unifamiliar ${ }^{49}$ impossibilitando a exploração da área pelo mercado imobiliário.

Apesar da intenção de incentivar a preservação e compensar os possíveis prejuízos do proprietário, a lei não teve muita aceitação ou efetividade naquele momento. Através dos arquivos da SMDU, onde se encontram não apenas o inventário da Z8-200, mas também registros das comunicações entre os órgãos e os proprietários desses bens culturais, é possível acompanhar alguns conflitos relativos à aplicação do instrumento. Um exemplo envolve as casas onde viveram 
Ramos de Azevedo e sua família, situadas na Rua Pirapitingui, n 11 1, 141 e 159. Em 1982, foi aberto no Condephaat um estudo para o tombamento desses bens, realizado pela historiógrafa Sheila Schvarzman e pela arquiteta Maria Cristina Wolff de Carvalho. A justificativa do tombamento excedeu a importância do arquiteto ou de suas obras individualmente, buscando reconhecer também questões urbanas, como as formas de se construir na cidade.

Em 1984, no entanto, após os proprietários serem notificados, o órgão recebeu contestações alegando que as casas não teriam "nenhum significado histórico ou artístico, muito menos 'valor excepcional' ou 'vinculação a fatos memoráveis' da história", 50 recorrendo-se ao texto do Decreto-Lei n²5/1937, ${ }^{51}$ que disciplina o tombamento federal, para deslegitimar o pedido. Um desses documentos, elaborado por parte da Santa Casa de Misericórdia, também reproduzia um trecho do parecer de Carlos Lemos (à época conselheiro do Condephaat) sobre esse caso, no qual se mostrava favorável ao tombamento e recomendava sua classificação como Z8-200 para beneficiar os proprietários com a transferência do direito de construir:

[...] à vista dos interesses da Santa Casa, altamente comprometidos com a preservação desse imóvel significativo, sugerimos seja a Prefeitura solicitada a declarar essa casa e suas duas companheiras (casas das filhas) como exemplares pertencentes à classificação Z8-200. Assim, seria possível a efetivação das transferências do direito de construir para outro local. Desse modo, a residência histórica estaria protegida sem prejuízos maiores aos proprietários. ${ }^{52}$

Percebe-se que Lemos defendia o instrumento como uma solução para evitar "prejuízos maiores aos proprietários", percepção que não foi compartilhada pelos contestantes. Eles alegavam que a classificação como Z8-200 era um "presente de grego", ou no máximo um "prêmio de consolação". 53 Ao analisar a lei relativa à transferência, os advogados avaliaram que ela não traria benefícios às proprietárias, primeiro por ser considerada eventual, "um direito abstrato", e segundo porque elas não teriam condições financeiras de construir com esse potencial adquirido. Os interessados, contudo, não chegaram a considerar no documento a venda do potencial, talvez em virtude da novidade do instrumento. Além disso, alegavam que mesmo a simples proposta de tombamento já teria colocado o imóvel "fora de comércio". Apesar dessas disputas, o conjunto foi tombado pelo Condephaat no ano seguinte. ${ }^{54}$

Instrumentos como a transferência do direito de construir se apoiam na ideia de que "a própria dinâmica do mercado imobiliário pode vir a financiar a garantia dos interesses públicos" 55 - no caso, a conservação dos bens culturais representativos para a sociedade. Ou seja, para que o instrumento tenha "sucesso", é preciso que a operação seja atraente para o investidor, pois é baseada numa transação entre
50. Vidigal (1984).

51. Brasil (1937).

52. Lemos (1982) apud Correia (1984, p. 3).

53. Ibid., p. 8.

54. Conselho de Defesa do Patrimônio Histórico, Arqueológico, Artístico e Turístico do Estado de São Paulo (1985).

55. Peretto et al. (2018, p. 4). 
56. Cf. Peretto (2017).

57. São Paulo (1984a, art. 11).

58. Freitas (1995) apud Somekh, op. cit.

59. Gaio (2002, p. 87) terceiros, sem financiamento do Estado. Possivelmente devido às restrições impostas, essa primeira legislação não gerou interesse. Corrobora essa hipótese o fato de apenas três imóveis protegidos à época terem solicitado a emissão da Declaração de Potencial Construtivo Transferível, ${ }^{56}$ documento necessário para realizar a transação. ${ }^{57}$ Dentre aqueles que solicitaram o documento, apenas uma transferência foi efetivada: "em 1989 foram transferidos 3.827,21 metros quadrados de um imóvel do Pateo do Collegio para uma nova sede da Cúria Metropolitana, projeto do escritório Rino Levi, que não chegou a ser construída". ${ }^{58}$

Nesse mesmo período, também foram registradas experiências relativas à aplicação da transferência do direito de construir para preservação do patrimônio cultural em outras cidades, à exemplo de Curitiba, que criou sua primeira legislação em 1982, bem como Porto Alegre, em 1987, 59 além de outras anteriores à promulgação do Estatuto da Cidade em 2001, que passou a prever a aplicação do instrumento em nível federal.

\section{A NORMATIZAÇÃO DA Z8-200}

Poucos dias após a promulgação da lei sobre a transferência do direito de construir, foi aprovado também o Decreto $n^{\circ} 19.835 / 1984$ para regulamentar o artigo $2^{\circ}$ da Lei $n^{\circ} 8.328 / 1975$, que instituía a Z8-200, determinando os níveis de preservação e intervenções admitidas nos bens culturais:

I - Nível de preservação 1 (P1): para edifícios cuja arquitetura deva ser preservada, tanto externa como internamente, sendo admitidos reparos, sem modificação da forma, vãos, estrutura e material utilizado, relativos a:

1 - consertos em pisos, paredes, murros, forros e revestimentos;

2 - consertos em esquadrias e escadas;

3 - reposição de telhas/elementos de suporte da cobertura, avariados ou deteriorados;

4 - consertos em instalações hidráulicas, elétricas e de gás;

II - Nível de preservação 2 (P2): para edifícios cuja arquitetura externa deva ser preservada, admitidos os reparos externos relacionados no ltem I, podendo ser objeto de reformas internas compatíveis com a preservação externa; 
III - Nível de preservação 3 (P3): para imóveis que são objeto de restrições especiais quanto a gabarito de altura e recuos, quando necessárias à preservação da volumetria dos conjuntos arquitetônicos classificados como P1 ou P2. 60

Foram propostos três níveis de preservação: o Pl determinava a proteção integral, mais restritiva, quando a arquitetura devia ser preservada tanto externa como internamente; O P2 era uma proteção parcial, quando apenas as características externas precisavam ser preservadas; e, por fim, o P3 era aplicado apenas para controle da volumetria. $O$ decreto também tratava dos logradouros e viadutos enquadrados na zona, que poderiam sofrer reparos e iluminação, desde que estes não implicassem alteração das características discriminadas na lei. Por exemplo, no caso do Largo da Memória (Z8-200-083), deveriam ser preservados os alinhamentos e a organização espacial, "árvores, muros, revestimentos, pavimentação, bancos, escadas, obelisco, fonte, luminárias, vias internas e complementos" ${ }^{61} \mathrm{~A}$ aprovação das intervenções permitidas para os imóveis P1 , P2 e P3 seria concedida pela Secretaria Municipal do Planejamento (Sempla), que ouviria quando necessário a Secretaria Municipal de Cultura (SMC), através do DPH. No caso dos imóveis tombados, as intervenções também ficariam sujeitas à prévia autorização do órgão responsável, estadual ou federal. ${ }^{62}$

A classificação de todos os imóveis da Z8-200 nos níveis de preservação foi anexada ao final do decreto, após análises, juntamente com uma série de diretrizes urbanísticas, demonstrando uma inserção da preservação do patrimônio cultural no planejamento urbano de maneira mais integrada nesse período. Os edifícios preservados em nível P3, por exemplo, admitiam demolição, mas só poderiam ser substituídos por outros de alinhamento, altura máxima e recuos estabelecidos nesse decreto, de modo a conservar a volumetria dos conjuntos arquitetônicos preservados total ou parcialmente, procurando manter assim a ambiência urbana. Neste sentido, a dinâmica se assemelha àquela dos imóveis da "área envoltória" ou "área de entorno" dos bens tombados, que muitas vezes também sofrem restrições e precisam ter suas intervenções aprovadas. Porém, no caso do tombamento, essas determinações são definidas caso a caso e constam em cada resolução, não existindo uma lei que normatiza todos os processos, como ocorrev em relação à Z8-200.

Essa normatização foi muito importante para que se justificasse a proteção e fossem estabelecidos seus limites. De acordo com Rabello, existe uma obrigatoriedade, para qualquer ato da administração pública, de haver clareza na demarcação do objeto, que é o "limite de incidência das obrigações", e na especificação das regras a serem observadas. Isto porque "não se pode cumprir o que não se conhece".$^{63} \mathrm{O}$ cidadão tem o direito de saber o que the é permitido
60. São Paulo (1984b).

61. Ibid., quadro I.

62. Ibid., art. $3^{\circ}, \S 2^{\circ}$.

63. Rabello, op. cit., p. 44. 
64. Fré, op. cit.

65. Informação verbal de Walter Pires. Entrevista concedida à autora em 5 de setembro de 2018 .

66. São Paulo (1987).

67. Id. (1984a). fazer em sua propriedade; logo, a inteligibilidade das diretrizes aplicáveis às áreas preservadas é fundamental para tornar a relação com a sociedade civil mais permeável e transparente. Segundo Fré, quando as intervenções eram estabelecidas via decreto, elas não estavam à mercê de interpretações diferentes com o decorrer do tempo, ou interpretações parciais, a critério do técnico ou conselheiro. Para ela, a subjetividade do tombamento pode fragilizar o processo, porque as regras de intervenção oscilam, nem sempre são claras e dependem da palavra final de um conselho que pode não ser "tão técnico e objetivo quanto gostaríamos". ${ }^{64}$

É relevante pontuar que em 1984 ainda não havia sido instituído o tombamento municipal e, embora o Conpresp tenha sido criado logo no ano seguinte, ele seria instalado definitivamente apenas ao final de 1988. Portanto, até então, a Z8-200 era o único instrumento de proteção municipal, enquanto o tombamento pertencia ao estado e à Federação. $\bigcirc$ controle dessas edificações também não foi outorgado a um setor específico de preservação, mas acomodado entre as demais incumbências do setor de planejamento, que em teoria poderia ampliar o potencial de integração do patrimônio nas dinâmicas de desenvolvimento urbano, muito embora não o tenha aproveitado de maneira significativa.

\section{CONFLITOS E DISSONÂNCIAS NA GESTÃO DO PATRIMÔNIO MUNICIPAL}

Conforme analisado até aqui, a Z8-200 foi criada na cidade de São Paulo em meados dos anos 1970, porém a legislação que a regulamentava, estabelecendo seus limites e proporcionando mecanismos de incentivo à preservação, foi instituída durante os anos 1980. Esse conjunto de leis, no entanto, não foi suficiente para evitar mais uma série de situações envolvendo a ameaça ou a perda de bens de interesse para a preservação na acidade. Esses fatos acabariam por gerar uma mobilização ainda na década de 1980 em favor da criação de um conselho municipal de preservação com maior autonomia. ${ }^{65} \mathrm{Na}$ época, não existia apenas o receio de perder exemplares relevantes do patrimônio paulistano pela ação lesiva de proprietários, como nos casarões da Avenida Paulista, mas também por circunstâncias políticas, mesmo nos casos em que existia a proteção pelo zoneamento.

Um exemplo ocorreu durante a gestão de Jânio Quadros como prefeito da cidade, marcada por decisões políiticas controversas. Após o estabelecimento de todo o aparato legal para dar suporte à proteção pela Z8-200, foi revertido ${ }^{66} \mathrm{em} 1987$ o enquadramento de uma série de casas entre a Rua Jandaia e a Rua da Assembleia que haviam sido protegidas por zoneamento em 1984.67 A reversão visava garantir a 
execução de um projeto viário e urbanístico que já vinha de gestões anteriores. Esse projeto previa a desapropriação dos imóveis, que se encontravam encortiçados, para que se construísse no lugar uma alça de acesso à Avenida 23 de Maio. Para viabilizálo, a prefeitura alterou a lei de zoneamento utilizando o expediente autoritário do decurso de prazo. Esse regime, criado durante a ditadura e ainda em voga naquele período inicial da redemocratização, determinava que o governante poderia encaminhar um PL ao Legislativo e solicitar que sua apreciação fosse feita em um prazo determinado, sob pena de ser considerado aprovado após a expiração. Assim, era possível ao Executivo invadir a função legislativa, desequilibrando os poderes. ${ }^{68}$

Sem discussões na Câmara ou com a sociedade, o casario que ocupava a conjunção daquelas vias foi desenquadrado da zona de preservação por intermédio desse recurso, após um processo de desapropriação e reintegração de posse por parte da prefeitura, quando os imóveis foram desocupados. ${ }^{69}$ Por fim, os edifícios foram demolidos em 1987,70 quando se revelaram os Arcos da Rua Jandaia que jaziam sob as construções, sendo apelidados à época de "Arcos do Jânio". 71 A descoberta, segundo Pires, ${ }^{72}$ não foi planejada, mas por acaso os arcos também apresentavam relevância histórica e ambiental, o que ocasionou sua valorização. Aquela importante camada do tecido urbano, no entanto, foi irremediavelmente perdida, juntamente com as relações sociais e de pertencimento que a população removida havia estabelecido com o lugar, que por muitos anos foi seu lar ou local de trabalho.

A decisão de demolir o casario foi muito criticada na época por arquitetos como Paulo Mendes da Rocha e Benedito Lima de Toledo, que se manifestaram através do jornal Folha de S.Paulo. ${ }^{73}$ Rocha afirmou que nada justificava "passar por cima do reconhecimento da comunidade do valor das casas". Toledo não participou diretamente do estudo de preservação desses exemplares para inclusão na Z8-200 - uma vez que o conjunto fazia parte dos enquadramentos mais recentes -, mas também aproveitou para criticar a forma arbitrária como vinha acontecendo a gestão da cidade. $\bigcirc$ jornal chegou a procurar o Condephaat à época, que alegou não ter instrumentos jurídicos para paralisar a obra, pois as casas não estavam tombadas ou em processo de tombamento.

As circunstâncias políticas se mostraram determinantes, portanto, não apenas para a inserção de novos bens na Z8-200 - que foi se rarefazendo com o decorrer do tempo por desinteresse do Legislativo -, mas também para a manutenção de sua salvaguarda. A confiança na proteção dos bens culturais pelo zoneamento foi abalada, e as reações à época dessas demolições demonstraram que o tombamento - que já vinha se estabelecendo como instrumento "mais difundido e mais sedimentado juridicamente"74 na proteção do patrimônio cultural no Brasil - era reconhecido como um recurso importante na preservação desse patrimônio, especialmente em situações
68. Gabardo; Neves (2016).

69. Cf. Muniz (2019).

70. Cf. Nascimento (2015b)

71. Cf. Id. (2015a).

72. Informação verbal. Entrevista concedida à autora em 5 de setembro de 2018 .

73. Prefeitura... (1987).

74. Rabello, op. cit., p. 46. 
75. Informação verbal. Entrevista concedida à autora em 5 de setembro de 2018. 76. Rabello, op. cit., loc. cit. 77. São Paulo (1985). de ameaça à sua integridade. Nesse cenário, foram organizadas as bases para a criação de um órgão de preservação na esfera municipal. Pires acredita que essa mobilização intencionava "replicar de alguma maneira um instrumento que já existia, seguindo o modelo que havia sido implementado no Condephaat e no próprio Iphan, com o tombamento a partir da deliberação de um conselho". ${ }^{75}$

Possivelmente também existiam outras disputas e negociações em curso no período, pois o patrimônio não permanece alheio aos diversos interesses conflitantes na competição pelo solo urbano. Porém, todas essas perdas e embates políticos do período contribuíram ou ao menos foram mobilizados como argumento para a criação do Conpresp e do tombamento municipal. Além da notoriedade do instrumento, que tem se tornado "quase sinônimo de qualquer ato de proteção do patrimônio cultural", 76 também estava embutida na instituição do Conselho a ideia de conquistar maior agilidade e autonomia na definição e aplicação legal da proteção dos bens, sem depender de deliberação da Câmara Municipal, como acontecia com a Z8-200.

\section{NOVOS RUMOS NA GESTÃO DO PATRIMÔNIO MUNICIPAL}

Diferentemente do Condepam, mencionado no início deste artigo, o Conpresp foi criado a partir de uma avaliação crítica da legislação do Condephaat e do Iphan, até por conta do maior distanciamento temporal. Suas atribuições principais eram deliberar sobre o tombamento na cidade, formular diretrizes da política de preservação e valorização dos bens culturais, promover a preservação e valorização da paisagem, definir as áreas de entorno dos bens tombados, opinar sobre planos, projetos e intervenções nesses bens e fiscalizar sua preservação e seu uso. A composição inicialmente proposta para esse conselho era bastante representativa, contemplando profissionais de diversas áreas do conhecimento, como arquitetos, historiadores, museólogos, arqueólogos, antropólogos, arquivistas e geógrafos, além da sociedade civil. Essa estrutura, porém, apesar de interessante, foi revista um ano depois, também por uma intervenção autoritária do governo de Quadros. Sua gestão voltou a utilizar o decurso de prazo e reduziu drasticamente a composição do Conpresp, que passou a ser constituído majoritariamente por representantes do Executivo.

tombamento no órgão foi instituído mediante o reconhecimento dos valores "cultural, histórico, artístico, arquitetônico, documental, bibliográfico, paleográfico, urbanístico, museográfico, toponímico, ecológico e hídrico", 77 demonstrando uma ampliação significativa do conceito de patrimônio. A dinâmica do tombamento era semelhante à que se estabeleceu nas demais esferas, proibindo 
a destruição, demolição e mutilação do bem tombado e submetendo pretensas intervenções à prévia autorização do órgão técnico de apoio e, se necessário, do Conselho. Uma diferença importante, porém, fruto de avaliação crítica, se encontra na determinação das áreas envoltórias: foi estabelecido o dimensionamento caso a caso por estudos do corpo técnico de apoio. ${ }^{78}$ Isso pode ser considerado um avanço em relação ao que se havia instaurado no Condephaat, por exemplo, com a determinação de um raio arbitrário de trezentos metros.

O DPH, que foi constituído desde 1975 e chegou a desenvolver trabalhos relacionados à Z8-200 junto à Sempla, foi designado na lei como órgão técnico de apoio ao Conpresp. A ele foram atribuídas as tarefas de fornecer os subsídios técnicos que fossem necessários ao Conselho, viabilizar suas decisões, encaminhar proposições e estudos pertinentes à questão da preservação para sua deliberação, divulgar suas decisões e administrar o Fundo de Proteção do Patrimônio Cultural e Ambiental Paulistano (Funcap). Esse fundo representa outro avanço na criação do Conpresp, tendo o objetivo de trazer alguma agilidade à aplicação de recursos para recuperação dos bens.

Apesar de ter sido criado em 1985, o Conpresp só seria instalado definitivamente ao final de 1988. Antes disso, porém, no início do mesmo ano, o prefeito Jânio Quadros tomou mais uma decisão controversa, instituindo junto ao seu gabinete o Programa de Recuperação do Patrimônio Histórico da Cidade de São Paulo, com o objetivo de "proceder ao levantamento da situação de todos os monumentos de São Paulo, promovendo as medidas necessárias para a devida conservação". 79 É importante salientar também que, mesmo com a criação do Conpresp, a Z8-200 não havia sido extinta. Assim, foi criado um terceiro mecanismo de preservação na cidade, anunciando de antemão um conflito na gestão municipal do patrimônio cultural. Quadros designou Emanuel Von Lauenstein Massarani para o cargo de coordenador-geral desse programa, tornando-o responsável por seu desenvolvimento. Massarani também exerceu posteriormente os cargos de superintendente do Patrimônio Cultural e presidente do Instituto de Recuperação do Patrimônio Histórico da Assembleia Legislativa do Estado (Alesp). ${ }^{80}$

$\bigcirc$ programa deveria ser custeado principalmente através do patrocínio de empresas e comunidades locais, com incentivos fiscais da "Lei Sarney" para a cultura, que havia sido criada em 1986. ${ }^{81}$ Essa lei precede a Rouanet e, até 1990, permitiu abater do Imposto de Renda doações (100\%), patrocínios (80\%) e investimentos (50\%) em cultura. ${ }^{82}$ A portaria que estabeleceu o programa ainda determinava que todas as secretarias municipais e, de modo especial, o DPH departamento que havia sido vinculado ao Conpresp no ato de sua criação deveriam colaborar com o coordenador-geral designado para essa tarefa. $\bigcirc$
78. Ibid., art. 10.

79. Id. (1988).

80. Cf. Museu... (2006).

81. Brasil (1986).

82. Cf. Lei... (2011). 
83. Instalação..., op. cit.

84. São Paulo (1989a).

85. O primeiro tombamento do órgão é de 1988, relativo a um imóvel da Avenida Brigadeiro Luiz Antônio, 42.

86. Somekh, op. cit.

87. Baffi, op. cit.

88. O planejamento ficava a cargo da Sempla, enquanto a preservação, na figura do Conpresp, estava ligada à SMC.

89. Fenelon (1995).

90. São Paulo (1992b).

91. Conselho Municipal de Preservação do Patrimônio Histórico, Cultural e Ambiental da Cidade de São Paulo (2002).

92. Brasil (1988, art. 23). choque de atribuições gerado ficou patente e acabou por causar o fim do programa. Sua execução teria possibilitado "a recuperação de vários monumentos", mas, devido à "mudança de gestão e para evitar o conflito de competências", 83 o programa foi extinto no início do ano seguinte, já no governo de Luíza Erundina. ${ }^{84}$ A essa altura já havia sido promulgada a Constituição Federal de 1988, destacando o dever do Estado na proteção do patrimônio cultural, e o Conpresp também já estava instalado e tombando..$^{85}$

Após o estabelecimento do Conpresp, segundo Somekh, a ação do DPH pautou-se por ampliar os inventários e abrir processos de tombamento. ${ }^{86}$ Nos anos 1980, o órgão passou a desenvolver uma metodologia para um inventário sistemático, que foi experimentado no bairro da Liberdade e originou o Inventário Geral do Patrimônio Ambiental, Cultural e Urbano de São Paulo (lgepac). Esses inventários, segundo Baffi, continuaram a ser realizados mesmo após a vinculação do DPH como órgão técnico de apoio ao Conpresp, em 1985.87 É importante lembrar, no entanto, que a Z8-200 também não havia deixado de existir com a instalação do órgão, logo os setores de planejamento e preservação, que pertenciam e ainda pertencem a secretarias distintas, ${ }^{88}$ continuaram a trabalhar em paralelo pela preservação do patrimônio cultural no município.

A partir de 1989, durante a gestão da prefeita Luiza Erundina, a historiadora Dea Fenelon esteve à frente do DPH e, segundo ela, o departamento procurou se aproximar da discussão da políica urbana na cidade de São Paulo ${ }^{89}$ - que sempre havia sido dominada pelo planejamento - para incluir questões como o direito à cidade e à memória. ${ }^{90}$ Ela destaca, desse período, o debate sobre a região do Bixiga, no bairro Bela Vista, que foi objeto de um concurso de ideias e de um inventário por parte do DPH. Em meio a esse trabalho de estudo e identificação, o órgão começou a perceber um aumento na pressão do mercado imobiliário na região e resolveu abrir um processo de tombamento já em 1990, que seria concluído em 2002. ${ }^{91}$ Alguns poucos imóveis do bairro já eram classificados como Z8-200 nesse período, portanto foi adicionada outra camada mais ampla de proteção.

Assim, entre 1988 e 2002, quando seria instituído o novo Plano Diretor, os imóveis poderiam ter até quatro camadas de proteção na cidade de São Paulo: pelo Iphan, Condephaat, Conpresp e pela Z8-200. Essa sobreposição é válida e havia sido prevista na Constituição Federal, que determinou ser de competência comum da União, dos estados, do Distrito Federal e dos municípios "proteger os documentos, as obras e outros bens de valor histórico, artístico e cultural, os monumentos, as paisagens naturais notáveis e os sítios arqueológicos". 92 No nível municipal, enquanto o Conpresp abria diversos processos de tombamento, a exemplo da Bela Vista, a Sempla continuou realizando alguns estudos de proteção para integrá-los à Z8-200, segundo Fré. Ela 
também defende que os órgãos protetores eram independentes entre si, porém mantinham "alguma comunicação". Com os governos pós-abertura democrática, no entanto, não teria sido possível aprovar novos enquadramentos na Câmara. ${ }^{93}$

Em 1992, o Conpresp decidiu abrir um processo de tombamento (Resolução $\left.n^{\circ} 44 / 1992\right)$ para todos os bens pertencentes à Z8-200.94 $\bigcirc$ processo foi aberto, segundo Pires, devido ao temor que existia dentro do órgão de preservação de que as Z8-200 fossem descartadas por decisões da Câmara novamente, como foi no caso do casario das ruas Jandaia e Assembleia. ${ }^{95}$ Assim, todos os imóveis passaram a ser submetidos, como os demais bens em exame, ao "mesmo regime de preservação do bem tombado até a decisão final do Conselho". 96 Apesar das sobreposições de proteção, não foi possível evitar a demolição ou modificações substanciais em alguns desses edifícios no decorrer dos anos. Na conclusão do tombamento, em 2016, seriam excluídos 412 lotes considerados sem interesse para a patrimonialização devido a demolições, "descaracterizações" e "perda de ambiência urbana". ${ }^{97}$ Ao final, seriam tombados 217 imóveis e dois logradouros pertencentes à antiga Z8-200. ${ }^{98}$

\section{CONSIDERAÇÕES FINAIS}

A criação da primeira zona especial de preservação cultural na cidade representou um importante passo no enfrentamento da questão pelo planejamento. A decisão de estabelecer essa política por meio do zoneamento não era consenso, conforme observado, mas foi fundamentada em discussões e experiências preservacionistas do período, que ampliaram a noção de patrimônio, envolvendo a ambiência urbana e procurando inserir a preservação cultural como uma problemática do planejamento. É importante considerar que, no contexto brasileiro, essas experiências que buscavam aliar preservação e legislação urbana estavam acontecendo não apenas em São Paulo, mas também em outras cidades. Um exemplo emblemático é o do Rio de Janeiro, com o projeto Corredor Cultural, de 1979, que combinava aspectos de zoneamento e preservação. Este também se estabeleceu em reação à onda de renovação urbana e de demolições de edifícios icônicos da área central da cidade. O Corredor Cultural, no entanto, logrou maior êxito e ficou amplamente conhecido no Brasil. Segundo Nascimento, é possível verificar seu sucesso como política de preservação pelas boas condições de conservação dos edifícios à época, se comparadas à situação destes no início dos anos 1980, assim como pela reapropriação do centro da cidade. ${ }^{99}$
93. Fré, op. cit.

94. São Paulo (1992d).

95. Informação verbal. Entrevista concedida à autora em 5 de setembro de 2018.

96. São Paulo (1985).

97. Conselho Municipal de Preservação do Patrimônio Histórico, Cultural e Ambiental da Cidade de São Paulo (2017).

98. Id. (2016).

99. Nascimento (2018). 
Já no caso de São Paulo, a pesquisa demonstrou que muitos dos bens que haviam sido protegidos pela Z8-200 foram perdidos ou descaracterizados. Mesmo após a instituição e o aprofundamento dos estudos referentes à Z8-200 em meados dos anos 1970, os anos 1980 foram marcados por demolições significativas de bens culturais na cidade, pela utilização de instrumentos arbitrários pelo Executivo e por conflitos de competência na gestão do patrimônio municipal. Como reação às perdas desse período, houve tentativas de ampliação do volume de bens protegidos e aprovação de novas leis para normatizar e incentivar a preservação por zoneamento. A proposta de criação de um instrumento de incentivo que fosse independente do investimento público representou um avanço importante neste sentido, na figura da transferência do direito de construir. $\bigcirc$ instrumento se materializou, porém, mais de dez anos após a criação da Z8-200, e sua aplicação não se mostrou efetiva, pois a configuração era ainda restrita e não conseguiu gerar interesse nos proprietários.

Assim, o período de consolidação da legislação urbanística de proteção ao patrimônio cultural na cidade foi marcado por turbulências e percalços. A despeito de todos os avanços, a preservação por zoneamento se demonstrou suscetível às contingências políiticas, como no caso dos casarões das ruas Jandaia e Assembleia, aumentando o apelo pela instituição de um conselho municipal de preservação com maior autonomia e poder de decisão. Nesse contexto, o tombamento - já reconhecido no país como um instrumento juridicamente forte de proteção do patrimônio cultural - foi mobilizado na criação do Conpresp, em 1985. Com o estabelecimento definitivo desse Conselho ao final de 1988, a ação do órgão concentrou-se na ampliação dos inventários e na abertura de processos de tombamento na cidade. Ao mesmo tempo, não foram aprovados novos enquadramentos na Z8-200, tornando-a praticamente inoperante. A preservação através do zoneamento, que já nasceu enfraquecida por circunstâncias políiticas, foi perdendo cada vez mais território. Pouco tempo depois, todos os bens dessa zona seriam objeto de um processo de tombamento pelo Conpresp, aberto em 1992; mas seus remanescentes, após mais de duas décadas, só passariam a ser salvaguardados definitivamente pelo órgão de preservação a partir de 2016.

Mediante a observação dos casos de perda ou ameaça à preservação dos bens culturais aqui relatados, esta pesquisa pode também provocar um debate importante, relativo aos usos do patrimônio. É possível refletir sobre como as atenções sempre se voltam para casos emblemáticos de demolição ou iminente perda do patrimônio cultural, ao passo que cotidianamente muitos deles se encontravam desocupados, subutilizados ou ocupados irregularmente. Logo, em essência, a questão da preservação está intimamente relacionada aos usos dos bens culturais, sobre os quais o tombamento não incide. $\bigcirc$ instrumento que $\circ$ 
município utiliza para realizar o controle do uso e da ocupação do solo é justamente o zoneamento. Uma zona de preservação, portanto, seria um instrumento oportuno para discutir uma questão importantíssima na preservação dos bens culturais, que são os seus usos. Mas o que se estabeleceu em relação a eles foi o silêncio.

No Programa Toledo/Lemos, talvez em virtude de uma visão influenciada pelo tombamento, os autores consideravam que a prefeitura não deveria cogitar disciplinar o uso dos bens culturais cadastrados, pois sendo estes propriedades particulares, caberia a seus donos discernir sobre o destino de suas posses. Ora, mas a prefeitura de fato já não disciplina os usos de todas as áreas da cidade através do zoneamento? Esses mecanismos já não restringem de alguma forma os direitos do proprietário? Porque se alguém possui um lote em área estritamente residencial e deseja construir nele um comércio, a lei o proíbe. Então, na prática, a prefeitura já opera com esses mecanismos e poderia utilizá-los na preservação dos bens culturais. Em vez de se tratar a questão, porém, foram permitidos para essas áreas os mesmos usos das zonas que as circundam, contanto que fossem compatíveis com as normas estabelecidas na resolução de tombamento. Ou seja, a lei foi omissa, delegando a responsabilidade à Secretaria de Cultura em vez de procurar compatibilizar essa demanda com as diretrizes de desenvolvimento urbano do município. E se o tombamento não interfere nos usos, que parâmetros existem? Retornamos, assim, ao caso a caso. 


\section{REFERÊNCIAS}

FONTES IMPRESSAS

CORREIA, Parabuçu Soares. Contestação à proposta de tombamento do Condephaat, Processo $n^{\circ}$ 22.365/82. Arquivo SMDU, 28 set. 1984. São Paulo: SMDU, 1984.

SÃO PAULO (cidade). Coordenadoria Geral de Planejamento. Programa Toledo/Lemos para a preservação de bens culturais arquitetônicos da área central de São Paulo. Arquivo SMDU. São Paulo: SMDU, 1977.

VIDIGAL, Geraldo de Camargo. Contestação à proposta de tombamento do Condephaat, Processo $n^{\circ}$ 22.365/82. Arquivo SMDU, 25 set. 1984. São Paulo: SMDU, 1984.

LIVROS, ARTIGOS E TESES

ANDRADE, Paula Rodrigues de. O patrimônio da cidade: arquitetura e ambiente urbano nos inventários de São Paulo da década de 1970. 2012. Dissertação (Mestrado em Arquitetura e Urbanismo) - Universidade de São Paulo, São Paulo, 2012.

BAFFI, Mirthes I. S. O Igepac-SP e outros inventários da Divisão de Preservação do DPH: um balanço. Revista do Arquivo Municipal, São Paulo, v. 204, p. 169-191, 2006.

BRASIL. Decreto-Lei n ${ }^{\circ} 25$, de 30 de novembro de 1937. Organiza a proteção do patrimônio histórico e artístico nacional. Diário Oficial da União, Rio de Janeiro, p. 24056, 6 dez. 1937.

BRASIL. Lei $\mathrm{n}^{\circ}$ 7.505, de 2 de julho de 1986. Dispõe sobre benefícios fiscais na área do imposto de renda concedidos a operações de caráter cultural ou artístico. Diário Oficial da União, Brasília, DF, p. 9763, 3 jul. 1986.

BRASIL. [Constituição (1988)]. Constituição da República Federativa do Brasil de 1988. Diário Oficial da União, Brasília, DF, 5 out. 1988.

CASTRIOTA, Leonardo Barci. Conservação urbana: tombamento e áreas de conservação. In: FERNANDES, Edésio; ALFONSIN, Betânia (coords.). Revisitando o Instituto do Tombamento. Belo Horizonte: Fórum, 2010. 
CONSELHO DE DEFESA DO PATRIMÔNIO HISTÓRICO, ARQUEOLÓGICO, ARTÍSTICO E TURÍSTICO DO ESTADO DE SÃO PAULO. Resolução SC 20/85. Residência Ramos de Azevedo - Rua Pirapitingui, 111, 141, 159. São Paulo: Condephaat, 1985.

CONSELHO MUNICIPAL DE PRESERVAÇÃO DO PATRIMÔNIO HISTÓRICO, CULTURAL E AMBIENTAL DA CIDADE DE SÃO PAULO. Resolução n ${ }^{\circ}$ 23/Conpresp/2016. Diário Oficial da Cidade de São Paulo, São Paulo, p. 58, 22 out. 2016.

CONSELHO MUNICIPAL DE PRESERVAÇÃO DO PATRIMÔNIO HISTÓRICO, CULTURAL E AMBIENTAL DA CIDADE DE SÃO PAULO. Resolução n ${ }^{\circ}$ 22/Conpresp/2016. Diário Oficial da Cidade de São Paulo, São Paulo, p. 14, 17 ago. 2017.

FELDMAN, Sarah. Planejamento e zoneamento: São Paulo, 1947-1972. São Paulo: Edusp: Fapesp, 2005.

FENELON, Dea Ribeiro. Políticas públicas em centros históricos: a experiência de São Paulo, 1989/1992. In: GOMES, Marco Aurélio A. de Filgueiras (org.). Pelo Pelô: história, cultura e cidade. Salvador: Edufba, 1995.

FENERICH, Antônia Regina Luz. Preservação em São Paulo: análise de procedimentos metodológicos. Dissertação (Mestrado em Arquitetura e Urbanismo) - Faculdade de Arquitetura e Urbanismo, Universidade de São Paulo, São Paulo, 2000.

FRÉ, Sylvia Maria Luz. Pesquisa acadêmica. Destinatário: Mariana Cavalcanti Pessoa Tonasso. [S. l.], out. 2018. Mensagem eletrônica. São Paulo, 03 e 09 out. 2018.

GABARDO, Emerson; NEVES, Ozias Paese. O estado de exceção e as normas aprovadas por decurso de prazo: uma história da exacerbação do Poder Executivo na ditadura de 1964. Cadernos da Escola de Direito e Relações Internacionais da UniBrasil, Curitiba, v. 3, n. 26, p. 66-80, 2016. Disponível em: <https://bit.ly/32glAao>. Acesso em: 28 fev. 2019.

GAIO, Daniel. A transferência do direito de construir e a efetiva proteção do patrimônio cultural e natural: alguns apontamentos sobre a experiência de Porto Alegre e Curitiba. In: FERNANDES, Edésio; RUGANI, Jurema Marteleto (orgs.). Cidade, memória e legislação: a preservação do patrimônio na perspectiva do direito urbanístico. Belo Horizonte: IAB-MG, 2002.

INSTALAÇÃO do primeiro Conselho - 20/10/1988. Cidade de São Paulo, São Paulo, 19 maio 2008. Disponível em: https://bit.ly/3oU2DUR. Acesso em: 28 fev. 2019.

CONPRESP. Resolução n ${ }^{\circ}$ 22/2002. Tombamento Bairro da Bela Vista. São Paulo, 2002.

LEI Sarney foi pioneira no incentivo à cultura. Senado Notícias, Brasília, DF, 20 dez. 2011. 
LEMOS, Carlos. A preservação da fisionomia paulistana. Módulo, Rio de Janeiro, n. 42, p. 3033,1976

MAYUMI, Lia. Taipa, canela preta e concreto: um estudo sobre a restauração de casas bandeiristas em São Paulo. 2006. Tese (Doutorado em Arquitetura e Urbanismo) - Universidade de São Paulo, São Paulo, 2006.

MUNIZ, Cláudia. O patrimônio como palimpsesto: revelando as camadas dos Arcos [do Bixiga], em São Paulo. In: CONGRESSO NACIONAL PARA A SALVAGUARDA DO PATRIMÔNIO, 2. 2019, Cachoeira do Sul. Anais [...]. Cachoeira do Sul: UFSM, 2019. p. 1-7.

MUSEU de Arte do Parlamento de São Paulo: um acervo de 920 obras em quatro anos de existência. Assembleia Legislativa do Estado de São Paulo, São Paulo, 24 jul. 2006. Disponível em: <https://bit.ly/381r4V4>. Acesso em: 5 nov. 2020.

NASCIMENTO, Douglas. A demolição da rua da Assembleia. São Paulo Antiga, São Paulo, 29 maio 2015a. Disponível em: <https://bit.ly/2EtNkMl>. Acesso em: 28 fev. 2019.

NASCIMENTO, Douglas. Os Arcos do Bixiga antes do Jânio. São Paulo Antiga, São Paulo, 15 maio 2015b. Disponível em: <https://bit.ly/38HNoGk>. Acesso em: 28 fev. 2019.

NASCIMENTO, Flávia Brito do. Blocos de memórias: habitação social, arquitetura moderna e patrimônio cultural. São Paulo: Edusp; Fapesp, 2016.

NASCIMENTO, Flávia Brito do. Corredor Cultural do Rio de Janeiro: debates e combates pelo patrimônio cultural urbano nos anos 1970. Patrimônio e Memória, São Paulo, v. 14, n. 2, p. 117139, julho-dezembro, 2018. Disponível em: <https://bit.ly/2TTfGYg>. Acesso em: 28 fev. 2019.

PERETTO, Flavia. Transferência do direito de construir na conservação dos imóveis tombados do município de São Paulo. In: SIMPÓSIO CIENTífICO ICOMOS BRASIL, 1., 2017, Belo Horizonte. Anais [...]. Belo Horizonte: Instituto Metodista Izabela Hendrix, 2017. p. 688-703.

PERETTO, Flavia Taliberti; OSKMAN, Silvio; SANTORO, Paula Freire; MENDONÇA, Pedro Henrique Rezende. Quando a transferência de potencial construtivo virou mercado: o caso de São Paulo. In: SEMINÁRIO DE HISTÓRIA DA CIDADE E DO URBANISMO, 15., Rio de Janeiro, 2018. Rio de Janeiro: UFRJ, 2018. p. 1-22. Disponível em: <https://bit.ly/2M0pzjn>. Acesso em: 18 ago. 2018.

PREFEITURA desocupa cortiços na rua da Assembleia. Folha de S.Paulo, São Paulo, ano 67, n. 98.59 , p. 11, 6 maio 1987. Primeiro caderno.

RABELLO, Sonia. Tombamento e legislação urbanística: competência e gestão. In: FERNANDES, Edésio; ALFONSIN, Betânia (coords.). Revisitando o Instituto do Tombamento. Belo Horizonte: Fórum, 2010. 
RODRIGUES, Marly. Imagens do passado: a instituição do patrimônio em São Paulo, 19691987. São Paulo: Editora Unesp, 2000.

RODRIGUES, Marly. Inventário de bens culturais: conhecer e compreender. In: Revista CPC, São Paulo, p. 31-48, jul. 2016. ISSN 1980-4466. Disponível em: <https://bit.ly/35gvNFE>. Acesso em: 08. fev. 2018.

SÃO PAULO (cidade). Decreto $\mathrm{n}^{\circ}$ 9.414, de 15 de março de 1971. Cria o Conselho de Defesa do Patrimônio Histórico e Cultural do Município. Diário Oficial do Município de São Paulo, São Paulo, p. 2, 16 mar. 1971a.

SÃO PAULO (cidade). Lei $n^{\circ} 7.688$, de 30 de dezembro de 1971. Dispõe sobre instituição do Plano Diretor de Desenvolvimento Integrado do Município de São Paulo - PDDI-SP, e dá outras providências. Diário Oficial do Município de São Paulo, São Paulo, p. 1, 31 dez. 1971 b.

SÃO PAULO (cidade). Lei $\mathrm{n}^{\circ} \mathbf{7 . 8 0 5}$, de 1 de novembro de 1972. Dispõe sobre o parcelamento, uso e ocupação do solo do município, e dá outras providências. Diário Oficial do Município de São Paulo, São Paulo, p. 1, 3 nov. 1972.

SÃO PAULO (cidade). Lei $\mathrm{n}^{\circ}$ 8.328, de 2 de dezembro de 1975. Dispõe sobre o parcelamento, uso e ocupação do solo no município, nas zonas de usos especiais Z8, cria novas zonas de uso, amplia zonas existentes e dá outras providências. Diário Oficial do Município de São Paulo, São Paulo, p. 1, 3 dez. 1975b.

SÃO PAULO (cidade). Lei n ${ }^{\circ} 8.848$, de 20 de dezembro de 1978. Dispõe sobre o parcelamento, uso e ocupação do solo na Zona Metrô-Leste - ZML, e dá outras providências. Diário Oficial do Município de São Paulo, São Paulo, p. 1, 21 dez. 1978c.

SÃO PAULO (cidade). Lei $n^{\circ}$ 9.725, de 2 de julho de 1984. Dispõe sobre a transferência de potencial construtivo de imóveis preservados; estabelece incentivos, obrigações e sanções, relativas à preservação de imóveis, e dá outras providências. Diário Oficial do Município de São Paulo, São Paulo, p. 5, 3 jul. 1984a.

SÃO PAULO (cidade). Decreto $n^{\circ} 19.835$, de 10 de julho de 1984 . Regulamenta o artigo $2^{\circ}$ da Lei $\mathrm{n}^{\circ}$ 8.328, de 2 de dezembro de 1975, e dá outras providências. Diário Oficial do Município de São Paulo, São Paulo, p. 1, 11 jul. 1984b.

SÃO PAULO (cidade). Lei $\mathrm{n}^{\circ}$ 10.032, de 27 de dezembro de 1985. Dispõe sobre a criação de um Conselho Municipal de Preservação do Patrimônio Histórico, Cultural e Ambiental da Cidade de São Paulo. Diário Oficial do Município de São Paulo, São Paulo, p. 1, 28 dez. 1985.

SÃO PAULO (cidade). Lei $\mathrm{n}^{\circ} 10.282$, de $1^{\circ}$ de abril de 1987 . Exclui imóveis do Quadro $\mathrm{n}^{\circ} \mathrm{8M}$, anexo à Lei $\mathrm{n}^{\circ}$ 9.725, de 2 de julho de 1984. Diário Oficial do Município de São Paulo, São Paulo, p. 1, 11 abr. 1987. 
SÃO PAULO (cidade). Portaria $n^{\circ} 130$, de 3 de março de 1988. Institui em Pref-G o Programa de Recuperação do Patrimônio Histórico da Cidade para levantamento da situação de todos os monumentos de São Paulo. Diário Oficial do Município de São Paulo, São Paulo, p. 1, 4 mar. 1988.

SÃO PAULO (cidade). Portaria $n^{\circ}$ 95, de 11 de janeiro de 1989. Declara extinto o Programa de Recuperação do Patrimônio Histórico da cidade, instituído pela Port. 130/88, junto ao Prefeito - Pref. Diário Oficial do Município de São Paulo, São Paulo, p. 1, 11 jan. 1989a.

SÃO PAULO (cidade). Departamento do Patrimônio Histórico. O direito à memória: patrimônio histórico e cidadania. São Paulo: DPH, 1992b.

SÃO PAULO (cidade). Resolução $\mathrm{n}^{\circ} 44$, de 15 de dezembro de 1992. Abre processo de tombamento dos imóveis enquadrados na Zona de Uso Z8-200, conforme especifica. Diário Oficial do Município de São Paulo, São Paulo, p. 35, 16 dez. 1992d.

SECRETARIA DE ESTADO DOS NEGÓCIOS METROPOLITANOS; EMPRESA METROPOLITANA DE PLANEJAMENTO DA GRANDE SÃO PAULO; SECRETARIA MUNICIPAL DO PLANEJAMENTO. Bens culturais arquitetônicos no município e na Região Metropolitana de São Paulo. São Paulo: Sempla, 1984.

SOMEKH, Nadia. Patrimônio cultural em São Paulo: resgate do contemporâneo? Arquitextos, São Paulo, ano 16, n. 185.08, 2015. Disponível em: <https://bit.ly/2POwI7q>. Acesso em: 8 ago. 2018.

TONASSO, Mariana Cavalcanti Pessoa. Zonas de conflito? Zoneamento e preservação do patrimônio cultural em São Paulo (1975-2016). 2019. Dissertação (Mestrado em Arquitetura e Urbanismo) - Universidade de São Paulo, São Paulo, 2019.

ZANETTI, Valdir Zonta. Planos e projetos ausentes: desafios e perspectivas da requalificação das áreas centrais de São Paulo. 2005. Tese (Doutorado em Arquitetura e Urbanismo) Universidade de São Paulo, São Paulo, 2006.

Artigo apresentado em: 5/1/2020. Aprovado em 12/8/2020. (cc) BY 